\title{
Using a sentinel colony of Apis mellifera (Hymenoptera: Apidae) to assess pesticides and food sources
}

Uso de una colmena centinela de Apis mellifera (Hymenoptera: Apidae) para evaluar presencia de plaguicidas y sus fuentes de alimentación

\footnotetext{
Martin Geria Reines ${ }^{1}$, Natacha Chacoff $1,2\left[0\right.$, Alexis Sosa ${ }^{3 \S}$, Alberto GalindoCardona $4,5^{*} \mathbb{D}$

1 Facultad de Ciencias Naturales e Instituto Miguel Lillo, Universidad Nacional de Tucumán. Miguel Lillo 251, (T4000JFE) San Miguel de Tucumán, Argentina.

2 Instituto de Ecología Regional, CONICET - Universidad Nacional de Tucumán. Casilla de Correo 34, (4107) Yerba Buena, Tucumán, Argentina.

3 Instituto Nacional de Tecnología Agropecuaria (INTA). EEA Concordia, Entre Ríos, Argentina.

4 Fundación Miguel Lillo. Miguel Lillo 251, (T4000JFE) San Miguel de Tucumán, Argentina.

5 Consejo Nacional de Investigaciones Científicas y Técnicas (CONICET), Argentina.

$\S$ Postumous author.

*Corresponding author: agalindo@tucuman-conicet.gov.ar (D)
}

\begin{abstract}
Honey bee populations are declining as occurs with other pollinators. One suggested cause of this decline is the impact of pesticides. To improve bees' health, pesticides and food sources may be monitored using sentinel hives, given that bees forage in a $2.5 \mathrm{~km}$ radius around the hive. We extracted 20 (twenty) bees, as well as samples of wax, honey and pollen from a sentinel hive. Six pesticides were detected in the samples, except for the honey. All detected pesticides in the sentinel hive are prohibited in Argentina. Eight different plant families and genera were detected in the honey and pollen samples. Our work suggests that monitoring pesticides with sentinel beehives will be useful to improve agricultural practices in the region.
\end{abstract}

Keywords - Coumaphos, foraging behavior, honey bee management, pollen, spiridiclophen.

Ref. bibliográfica: Geria Reines, M.; Chacoff, N.; Sosa, A.; Galindo-Cardona, A. 2021. Using a sentinel colony of Apis mellifera (Hymenoptera: Apidae) to assess pesticides and food sources". Acta zoológica lilloana 65 (2): 182-188. doi: https://doi.org/10.30550/j.azl/2021.65.2/2021-06-23

> Recibido: 1 de febrero 2021 - Aceptado: 23 de junio 2021.

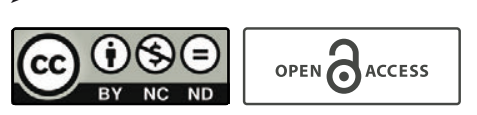

- URL de la revista: http://actazoologica.lillo.org.ar

- Esta obra está bajo una Licencia Creative Commons Atribución - No Comercial - Sin Obra Derivada 4.0 Internacional. 


\section{RESUMEN}

Las poblaciones de abejas melíferas están disminuyendo, como ocurre con otros polinizadores. Una de las causas sugeridas de este declive es el impacto de los pesticidas. Para mejorar la salud de las abejas, se pueden monitorear los pesticidas y las fuentes de alimentación mediante colmenas centinela, dado que las abejas pecorean en un radio de $2,5 \mathrm{~km}$ alrededor de la colmena. Extrajimos 20 (veinte) abejas, así como muestras de cera, miel y polen de una colmena centinela. Se detectaron seis plaguicidas en las muestras, excepto en la miel. Todos los plaguicidas detectados en la colmena centinela están prohibidos en Argentina. Se detectaron ocho familias y géneros de plantas diferentes en las muestras de miel y polen. Nuestro trabajo sugiere que el monitoreo de plaguicidas con colmenas centinela será útil para mejorar las prácticas agrícolas en la región.

Palabras clave - Coumafos, comportamiento de pecoreo, manejo de abejas melíferas, polen, espiridiclofeno.

Populations of Apis mellifera L. and other pollinators have diminished in the last years as a result of a combination of factors (IPBES, 2016, Requier et al., 2018), including the pervasive use of pesticides in agricultural fields (Porrini et al., 2016). Honeybee colonies depend on floral resources in the surroundings, where bees forage for pollen and nectar in a radius of $1-2 \mathrm{~km}$ up to $10 \mathrm{~km}$ (Couvillon et al., 2015). When foraging, workers are exposed to xenobiotic substances (e.g. pesticides) that may have arrived at the crop and non-crop flowers (Poquet et al., 2016); non-lethal effects of this exposure include alterations in development, orientation, mobility, sleep patterns, and circadian rhythm (Vázquez et al., 2020). Sentinel honeybee hives, which are colonies that have been isolated from the apiary and left unmanaged, have been used to study these pesticides' effects on bees. In addition, individual (Traynor et al., 2016) or multiple (Van der Steen et al., 2015) sentinel hives have been used to assess the surrounding environment in terms of available food resources, climatic effects, and land use changes. In addition, these hives have been used to detect pests' geographical expansion (e.g., Chalup et al., 2018), and are especially useful to study aspects of bees' behavior without the effect of the high densities observed in apiaries.

Monitoring the implementation and use of pesticides and their consequences on bees' health is a valuable tool to improve the sustainability of agriculture. At the same time, monitoring the plant species that bees use enables the design of optimal landscapes for bees' productivity. Our objectives were to survey pesticides that bees incorporated into a sentinel hive and to identify the main plant species that bees use for adult and larvae food in a subtropical agroforestry-natural environment.

This experiment was conducted in an agroforestry-natural border, surrounded by crop fields, within the Yungas biome in Argentina (2647'28.6”S, 65'19'33.9'W; Fig. 1), which has a subtropical climate with seasonal rains during the summer. One healthy hive was isolated, before the beginning of the experiment, from other hives 

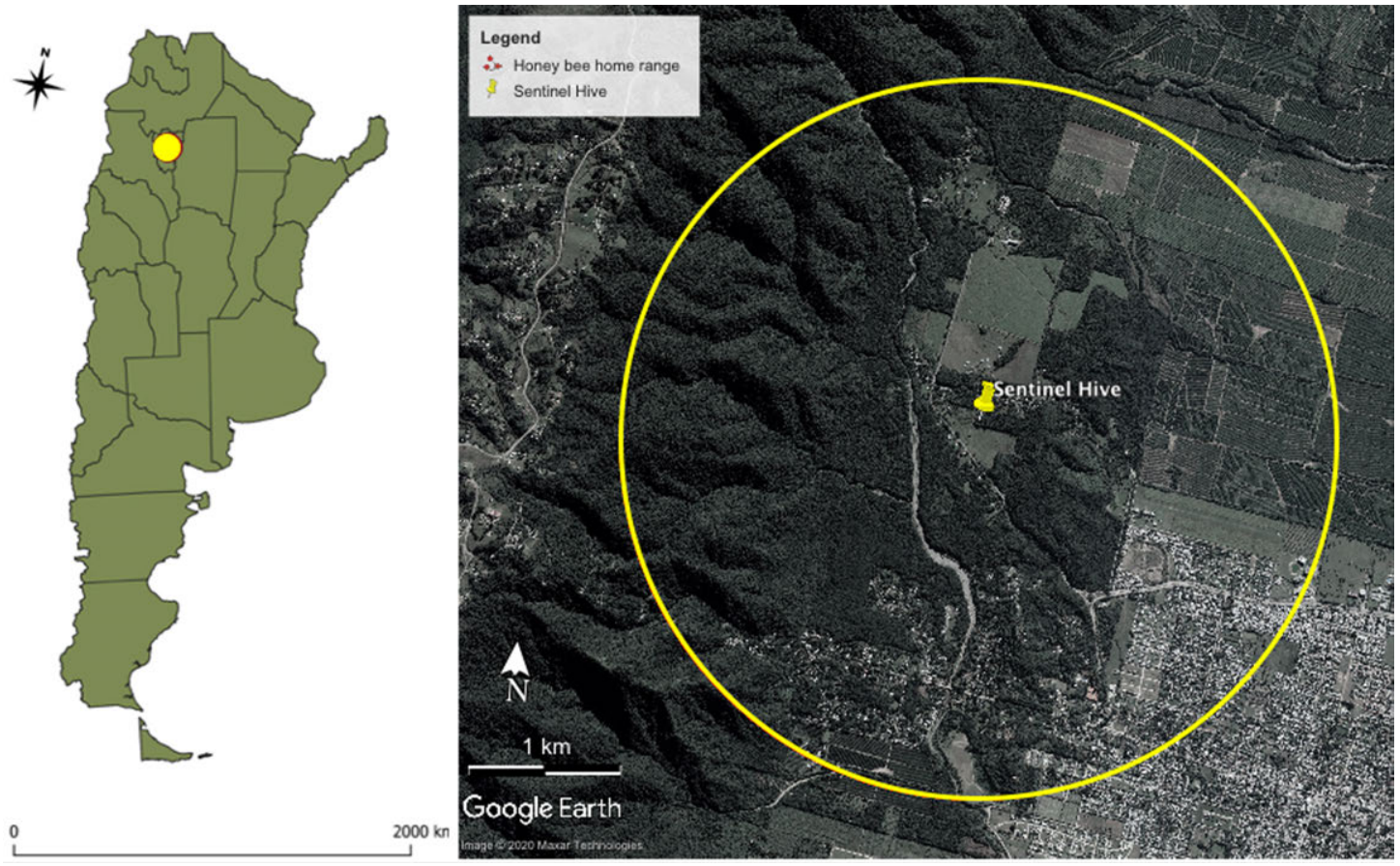

Figure 1. Left image: map of Argentina and study area shown with the yellow circle. Right image: home range of forager honey bees at our field station in the Escuela de Agricultura y Sacarotecnia, Argentina.

Figura 1. Imagen de la izquierda: mapa de Argentina y zona de estudio indicada con el círculo amarillo. Imagen de la derecha: rango de hogar de las abejas melíferas pecoreadoras en nuestro apiario experimental en la Escuela de Agricultura y Sacarotecnia, Argentina.

for at least 16 days, and then used as sentinel hive. We monitored the hive for one month in the middle of the 2019 summer season.

For the pesticides assessment we collected one $50 \mathrm{ml}$ sample from each of four matrices within the hive: virgin's beeswax, adult bees ( 20 individuals), honey, and stored pollen. For pesticides analysis we used the multi-residue analysis of pesticides (developed and validated by Herrera et al., 2016, Niell et al., 2017, and García et al., 2017). High Performance Liquid Chromatography analysis (HPLC) was used to determine the presence/absence of 90 pesticides on each sampled and to quantify other 37 pesticides (Appendix). This process consists of two stages, in the first stage the pesticides are extracted using acetonitrile and other salts and on the second stage the pesticide analyses take place, using mass spectrometry and liquid chromatography.

Pesticides were classified in classes according to toxicity and target, in accordance to the Ministry of Agriculture and Fisheries of Argentina (Gallo, 2006). To characterize the floral environment visited by bees, we have also conducted a palynological analysis in honey and pollen collected from the hive.

Six xenobiotics compounds were found in three of the four analyzed matrices (Table 1). Bees presented three pesticides on their bodies, suggesting that they could have been affected while foraging in the surrounding crops. Coumaphos, ametryn, and carbendazim were found in the beeswax samples. No pesticides were detected in the honey matrix. The pesticides concentrations were below the lethal levels, but all detected pesticides are prohibited or restricted under Argentinian regulations. 
Table 1. Concentration of the pesticides detected on each of the sampled matrices in this study and classification by toxicity in Argentina (Gallo 2006, Imtrade Australia 2014, IUPAC 2021, Minnesota Department of Agriculture 2021, Universal crop protection 2015, Gregorc et al., 2018, Interoc 2015).

Tabla 1. Concentración de los plaguicidas detectados en cada una de las matrices muestreadas en este estudio y clasificación por toxicidad en Argentina (Gallo 2006, Imtrade Australia 2014, IUPAC 2021, Minnesota Department of Agriculture 2021, Universal crop protection 2015, Gregorc et al., 2018, Interoc 2015).

\begin{tabular}{|l|c|c|c|c|c|c|c|c|}
\hline Pesticides & $\begin{array}{c}\text { Wax } \\
(\mathbf{u g} / \mathbf{k g})\end{array}$ & $\begin{array}{c}\text { Pollen } \\
(\mathbf{u g} / \mathbf{k g})\end{array}$ & $\begin{array}{c}\text { Bees } \\
(\mathbf{u g} / \mathbf{k g})\end{array}$ & $\begin{array}{c}\text { Honey } \\
(\mathbf{u g} / \mathbf{k g})\end{array}$ & Class & Type & Comment & $\begin{array}{c}\text { Oral LD50 } \\
(\mathbf{u g} / \mathbf{b e e})\end{array}$ \\
\hline Coumaphos & 82 & 0 & 0 & 0 & No Class. & Acaricide & Toxic for bees & $3-6$ \\
\hline Spirodiclophen & 0 & 8 & 10 & 0 & 4 & Acaricide & Toxic for bees & $>100$ \\
\hline Carbendazym & 2 & 0 & 14 & 0 & 4 & Fungicide & Extremely toxic & 50 \\
\hline Triphloxystrobin & 0 & 0 & 3 & 0 & 4 & Fungicide & Extremely toxic & $>208.8$ \\
\hline Pyraclostrobin & 0 & 0 & 4 & 0 & 2 & Fungicide & $\begin{array}{c}\text { Moderately toxic } \\
\text { for bees }\end{array}$ & $>110$ \\
\hline Ametryn & 2 & 0 & 0 & 0 & 3 & Herbicide & $\begin{array}{c}\text { Moderately toxic } \\
\text { for bees }\end{array}$ & $>100$ \\
\hline
\end{tabular}

The pollen analysis showed that bees collected nectar from eight different plant families (pollen present in the honey sample) and pollen from three plant families (samples from stored pollen). The Myrtaceae family and eight plant genera were found both in honey and pollen. Other plant families found only in honey samples were: Rutaceae (Citrus sp.); Sapindaceae (Allophyllus edulis Camb.); Boraginaceae (Heliotropium sp.); Piperaceae (Piper sp.); Junglandaceae (Juglans sp.), and Oleaceae (Ligustrum lucidum Ait, Fraxinus sp.). Taking these results into consideration, one could speculate that a bee has a bigger chance at getting exposed to pesticides by collecting pollen since the greater the diversity of food sources the risk of exposure to pesticides decreases (Smart et al., 2016).

The acaricide coumaphos was the most concentrated pesticide detected in our study. At sublethal doses, coumaphos produces erratic movements in bees (Williamson and Wright, 2013), and a concentration of $10 \mathrm{mg} / \mathrm{kg}$ in beeswax, which is higher than the one found in this study, can contaminate honey (Kochansky et al., 2001). Detoxification from this acaricide by bees has been observed due to the action of three groups of enzymes (Mao et al., 2013); but given that multiple pesticides where present in our sentinel hive, the efficiency of these metabolic pathways might be decreased. Though we can't assert this hypothesis, because we didn't carry out an enzyme analyses in our sentinel hive. Accordingly, we might expect that the bees in our study could have behavioral alterations, including disorientation, which could be studied using microchips in bees (Ayup et al. 2021).

Our study shows how the use of sentinel hives for the monitoring of both, pesticides and food resources within beehives, might shed valuable information not only to design sustainable agri-environments, but also it could be used by beekeepers and regulatory organisms. 


\begin{tabular}{|c|c|c|c|c|}
\hline Pesticidas & Abeja & Miel & Cera & Polen \\
\hline 3H Carbofuran & ND & ND & ND & ND \\
\hline Acetamiprid & ND & ND & ND & ND \\
\hline Ametryn & ND & ND & 2 & ND \\
\hline Azoxystrobin & ND & ND & ND & ND \\
\hline Benalaxyl & ND & ND & ND & ND \\
\hline Benzoximate & ND & ND & ND & ND \\
\hline Boscalid & ND & ND & ND & ND \\
\hline Carbaryl & ND & ND & ND & ND \\
\hline Carbendazim & 14 & ND & 2 & ND \\
\hline Carbofuran & ND & ND & ND & ND \\
\hline Chlorpyrifos & ND & ND & ND & ND \\
\hline Coumaphos & ND & ND & 82 & ND \\
\hline Cyprodinil & ND & ND & ND & ND \\
\hline Difenoconazole & ND & ND & ND & ND \\
\hline Dimethoate & ND & ND & ND & ND \\
\hline Dimoxystrobin & ND & ND & ND & ND \\
\hline Fipronil & ND & ND & ND & ND \\
\hline Fludioxonil & ND & ND & ND & ND \\
\hline Flufenoxuron & ND & ND & ND & ND \\
\hline Fluoxastrobin & ND & ND & ND & ND \\
\hline Fluxapyroxad & ND & ND & ND & ND \\
\hline Imazalil & ND & ND & ND & ND \\
\hline Imidacloprid & ND & ND & ND & ND \\
\hline Malathion & ND & ND & ND & ND \\
\hline Methiocarb & ND & ND & ND & ND \\
\hline Picoxystrobin & ND & ND & ND & ND \\
\hline Prochloraz & ND & ND & ND & ND \\
\hline Propoxur & ND & ND & ND & ND \\
\hline Pyracarbolid & ND & ND & ND & ND \\
\hline Pyraclostrobin & 4 & ND & ND & ND \\
\hline Pyrimethanil & ND & ND & ND & ND \\
\hline Quinalphos & ND & ND & ND & ND \\
\hline Quinoxyfen & ND & ND & ND & ND \\
\hline Spirodiclofen & 10 & ND & ND & 8 \\
\hline Tebuconazole & ND & ND & ND & ND \\
\hline Thiabendazole & ND & ND & ND & ND \\
\hline Thiophanathe-methyl & ND & ND & ND & ND \\
\hline Trifloxystrobin & 3 & ND & ND & ND \\
\hline
\end{tabular}

\section{ACKNOWLEDGEMENTS}

Thanks to the Escuela de Agricultuta y Sacarotecnia and Laboratorio de Palinología of the National University of Tucumán, Argentina. Thanks to students and colleagues that collaborated with data gathering and manuscript edition. We are grateful for the comments of two anonymous reviewers. This work is the product of Martin Geria's final work for his bachelor's degree at the Faculty of Natural Sciences, UNT.

\section{FINANCING}

This research received no external funding. 


\section{PARTICIPATION}

MG and AGC participated in all research processes. NC participated in the experimental design and article writing. AS analyzed the samples for pesticides.

\section{CONFLICT OF INTEREST}

No potential conflict of interest was reported by the authors.

\section{LITERATURE CITED}

Ayup, M. M., Gärtner, P., Agosto-Rivera, J. L., Marendy, P., de Souza, P., GalindoCardona, A. (2021). Analysis of Honeybee Drone Activity during the Mating Season in Northwestern Argentina. Insects, 12, 566. https://doi.org/10.3390/insects 12060566

Chalup, A., Ayup, M. M., Monmany Garzia, A. C., Malizia, A., Martin, E., De Cristobal, R., Galindo-Cardona, A. (2018). First report of the lesser wax moth Achroia grisella F. (Lepidoptera: Pyralidae) consuming polyethylene (silo-bag) in northwestern Argentina. Journal of Apicultural Research, 57, 569-571. doi: 10.1080/00218839.2018.1484614.

Couvillon, M. J., Riddell Pearce, F. C., Accleton, C. Fensome, K. A. Quah, S., Taylor, E. L., Ratnieks, F. (2015). Honey bee foraging distance depends on month and forage type. Apidologie, 46, 61-70. https://doi.org/10.1007/s13592-014-0302-5

Enviromental Protection Authority. (2018). Science memo for the reassessment of the approval to import or manufacture Luna Sensation for release (APP203261). pp: 27.

Gallo Mendoza, G. (2006). Agroquímicos prohibidos o restringidos: Normas Reguladoras de Procedimientos para evitar la contaminación. PRAT-DNAyF-SSAGyFSAGPyA-ME. (http://www.alimentosargentinos.gob.ar/bpa/bibliografia/Minagro_Agroquimicos_prohibidos.pdf).

García, M. D. G., Duque, S. U., Fernandez, A. B. L., Sosa, A., Fernandez-Alba, A. R. (2017). Multiresidue method for trace pesticide analysis in honeybee wax comb by GC-QqQ-MS. Talanta 163, 54-64.

Gregorc, A., Alburaki, M., Rinderer, N., Sampson, B., Knight, R. P., Karim, S., Adamczyk, J. (2018). Effects of coumaphos and imidacloprid on honey bee (Hymenoptera: Apidae) lifespan and antioxidant gene regulations in laboratory experiments. Scientific Reports, 8, 15003.

Herrera López, S., Lozano, A., Sosa, A., Hernando, M. D., Fernández-Alba, A. R. (2016). Screening of pesticide residues in honeybee wax comb by LC-ESI-MS/ MS. A pilot study. Chemosphere. https://doi.org/10.1016/j.chemosphere.2016.0 7.008

Imtrade Australia. Imtrade Carbendazim 500SC Fungicide. Safety data sheet. (2014). pp: 5. 
Intergovernmental Science-Policy Platform on Biodiversity and Ecosystem Services (IPBES). (2016). The assessment report on pollinators, pollination and food prodution. pp 152-188.

IUPAC. Pyraclostrobin (Ref: BAS 500F). (2021).

Kochansky, J., Wilzer, K., Feldlaufer, M. (2001). Comparison of the transfer of coumaphos from beeswax into syrup and honey. Apidology 32, 119-125.

Mao, W., Schuler, M. A. Berenbaum, M. R. (2013). Honey constituents up-regulate honey bee genes. Proceedings of the National Academy of Sciences of the United States of America. 110, 8842-8846.

Minnesota Department of Agriculture. https://www.mda.state.mn.us/protecting/ bmps/pollinators/beetoxicity

Niell, S., Jesús, F., Pérez, N., Pérez, C., Pareja, L., Abbate, S., Carrasco Letelier, L., Díaz, S., Mendoza, Y., Cesio, V., Heinzen, H. (2017). Neonicotinoids transference from the field to the hive by honey bees: Towards a pesticide residues biomonitor. Science of Total Environment 581-582, 25-31.

Poquet, Y., Vidau, C., Alaux, C. (2016). Modulation of pesticide response in honeybees. Apidologie 47, 412-426. https://doi.org/10.1007/s13592-016-0429-7

Porrini, C., Mutinelli, F., Bortolotti, L., Granato, A., Laurenson, L., Roberts, K., Gallina, A., Silvester, N., Medrzycki, P., Renzi, T., Sgolastra, F. \& Lodesani, M. (2016). The Status of Honey Bee Health in Italy: Results from the Nationwide Bee Monitoring Network. PLoS ONE 11, e0155411. https://doi.org/10.1371/ journal.pone.0155411

Requier, F., Antúnez, K., Morales, C., Aldea Sánchez, P., Castilhos, D., Garrido, P., Giacobino, A., Reynaldi, F., Rosso Londoño, M., Santos, E., Garibaldi, L. (2018) Trends in beekeeping and honey bee colony losses in Latin America, Journal of Apicultural Research, 57:5, 657-662, DOI: 10.1080/00218839.2018.1494919

Smart, D. M., Pettis, S. J., Eulis, N., Spivak, S. M. (2016). Land use in the North Great Plains region of the U.S. influences the survival and productivity of honey bee colonies. Agriculture, Ecosystems and Environment 230, 139-149.

Traynor, K., Pettis, J., Tarpy, D. R., Mullin, A. C., Frazier, L. J., Frazier, M., vanEngelsdorp, D. (2016). In-hive Pesticide Exposome: Assessing risks to migratory honey bees from in-hive pesticide contamination in the Eastern United States. Scientific Reports 6, 33207. https://doi.org/10.1038/srep33207

UNIVERSAL Crop Protection (Pty) Ltd. Material safety data sheet. Universal ametryn 500sc. (2015). pp: 3.

Van der Steen, J. J., de Kraker, J., Grotenhuis, T. (2015). Assessment of the potential of honeybees (Apis mellifera L.) in biomonitoring of air pollution by cadmium, lead and vanadium. Journal of Environmental Protection, 6, 96.

Vázquez, D. E., Balbuena, M. S., Chaves, F., Gora, J., Menzel, R., Farina, W. M. (2020). Sleep in honey bees is affected by the herbicide glyphosate. Scientific Reports, 10, 1-8.

Williamson, S. M., Wright, G. A. (2013). Exposure to multiple cholinergic pesticides impairs olfactory learning and memory in honeybees. Journal of Experimental Biology, 216, 1799-1807. 